\title{
Quality of life of patients with strabismus
}

\author{
Qualidade de vida em pacientes estrábicos
}

Geraldo de Barros Ribeiro ${ }^{1}$, Ana Gabriela Zum Bach ${ }^{1}$, Camila Maia Faria ${ }^{1}$, Suze Anastásia ${ }^{1}$, Henderson Celestino de Almeida ${ }^{1}$

\begin{abstract}
Purpose: To evaluate the impact of strabismus on quality of life.

Methods: This cross-sectional study included 101 individuals aged 7-67 years with strabismus. They were interviewed and made to answer a questionnaire with 20 questions intended to assess the individual's interaction with their social and working environment, sensory perception, and limitations in their daily lives. There were five types of possible responses for each question: never, rarely or very few times, sometimes, frequently, and always. The questionnaire was based on the AS-20 and contained 11 questions assessing psychosocial aspects and 9 questions assessing functional aspects. Among those who were interviewed, $24.8 \%$ had undergone surgical correction of strabismus.

Results: We observed a significant impact of strabismus on the quality of life of the interviewed individuals. Feelings of sadness and inferiority because of strabismus were reported by $74.2 \%$ and $58.4 \%$ respondents, respectively. In terms of functionality, $12.1 \%$ reported difficulty in reading, $14 \%$ said they had difficulty in depth perception (stereopsis), and $17.8 \%$ frequently or always associated pain or burning sensation in the eyes to strabismus. A significant difference was detected in the quality of life scores for the psychosocial aspect among patients who had and had not undergone surgery (Wilcoxon test, 158; $p<0.001$ ). Individuals who had undergone surgery had a better quality of life from the psychosocial perspective. Conclusions: In this evaluation, we found a significant negative interference of strabismus on quality of life from both the functional and psychosocial perspectives. This demonstrated the importance of treatment for strabismus, regardless of age, because it can interfere with the functional well-being of the individual.
\end{abstract}

Keywords: Strabismus/physiopathology; Social behavior; Quality of life; Questionnaires

\section{RESUMO}

Objetivo: Avaliar a interferência do estrabismo na qualidade de vida em indivíduos estrábicos.

Métodos: Estudo transversal envolvendo 101 indivíduos estrábicos entre 7 e 67 anos. Eles foram entrevistados e responderam um questionário com 20 perguntas aplicadas pelos pesquisadores. As perguntas tinham como objetivo avaliar a interação do indivíduo com o seu meio social, de trabalho, percepção sensorial e limitações na sua vida diária, com cinco tipos de respostas para cada pergunta: nunca, raramente ou muito pouco, algumas vezes, frequentemente e sempre. O questionário foi baseado no AS-20 e contendo 11 questões avaliando aspectos psicossociais e 9 questões avaliando aspectos funcionais. Entre os indivíduos entrevistados, 24,8\% haviam sido submetidos a correção cirúrgica do estrabismo.

Resultados: Observou-se impacto significativo do estrabismo sobre a qualidade de vida dos indivíduos avaliados. Sentir-se incomodado ou inferiorizado em decorrência do estrabismo foram relatados por $74,2 \%$ e 58,4\% dos entrevistados respectivamente. No quesito de funcionalidade, $12,1 \%$ relataram dificuldade para ler, $14 \%$ disseram ter dificuldade na percepção de profundidade (estereopsia) e 17,8\% associaram dor ou ardor nos olhos ao estrabismo frequentemente ou sempre. Diferença significativa foi detectada com respeito ao escore de qualidade de vida no aspecto psicossocial entre indivíduos que realizaram e não realizaram cirurgia (teste de Wilcoxon =158, p-valor $<0,001)$. Indivíduos que realizaram cirurgia possuíam melhor qualidade de vida no aspecto psicossocial.

Conclusões: Nessa avaliação, percebe-se uma interferência negativa muito significativa do estrabismo na qualidade de vida, tanto funcional como psicossocial nos indivíduos pesquisados. Isso demonstra a importância do tratamento do estrabismo, independente da idade, pois ele pode interferir muito na qualidade de vida e bem estar psicossocial e funcional do indivíduo.

Descritores: Estrabismo/fisiopatologia; comportamento social; Qualidade de vida; Questionários

\section{INTRODUCTION}

Strabismus is one of the ophthalmological problems that can affect the quality of life of individuals. The quantitative assessment of the quality of life of patients with strabismus may be an important addition to clinical examination because it allows for a greater understanding of the condition and a proper assessment of the effectiveness of treatment ${ }^{(1)}$.

The main purpose of strabismus treatment is the alignment of the visual axes in order to achieve single binocular vision with good image fusion. Other advantages of strabismus correction include the improvement of any abnormal head posture, expansion of the visual field, restoration of stereoscopic acuity, centralization of the visual field, elimination of diplopia, improvement in ocular motility, improvement in psychomotor development, and restoration of normal appearance ${ }^{(2-7)}$.

Both children and adults with strabismus suffer frequently from various psychosocial and emotional problems such as low self-esteem, negative social prejudice, school bullying, increased social anxiety, fragile interpersonal relations, and job opportunity issues. Strabismus is known by the lay population only as a physiognomic esthetic defect that causes damaged self-esteem and hinders relationships and psychosocial relations. Many authors condemn the use of the terms esthetic or cosmetic for the treatment of strabismus because these terms mean "something made to improve or embellish." However,
Funding: No specific financial support was available for this study.

Disclosure of potential conflicts of interest: None of the authors have any potential conflicts of interest to disclose.

Corresponding author: Geraldo de Barros Ribeiro. Av. Silviano Brandão, 1600 - Belo Horizonte (MG) - 31015-015 - Brazil - E-mail: gbarrosribeiro@gmail.com

Approved by the Research Ethics Committee of the Hospital das Clínicas at UFMG on 09/28/2011 
strabismus is a pathological state caused by a process from an underlying disease associated with abnormal binocular vision that leads to a change in the normal appearance of an individual and can affect the quality of life $e^{(8-12)}$.

In recent years, many studies have evaluated the strabismus-related quality of life (SRQOL). There are some specific instruments for SRQOL assessment, which were elaborated on the basis of interviews with patients and their relatives. Feelings and expressions have been thus collected and used by doctors and researchers for the development of more objective and efficient questionnaires for measuring the impact of strabismus on the patients' quality of life ${ }^{(13-17)}$.

In 2009, the AS-20 questionnaire was developed for the assessment of SRQOL. It can be used in everyday clinical practice or as a research tool and can be filled out by the patient without supervision. The full version is available with no restrictions as long as it is identified by quoting its original description ${ }^{(13)}$. On this basis, we developed a similar questionnaire with small changes caused by cultural differences and forms of expression in our country. The questionnaire established by our department was conducted by the researchers instead of being filled out by the patient alone. With this, we could better explain the purpose of the research and the questions, making it possible for use in children aged $>8$ years. The purpose of this study was to assess and compare the psychosocial, emotional, and functional consequences of strabismus in a portion of the Brazilian population.

\section{METHODS}

This study was approved by the Research Ethics Committee of the Hospital das Clínicas at Universidade Federal de Minas Gerais (UFMG) on 09/28/2011. It was conducted in the Strabismus Sector of Hospital São Geraldo at UFMG. A semistructured interview was conducted with individuals aged $>7$ years old after their parents provided written informed consent. The patients underwent identification and complete eye examination. A questionnaire assessing strabismus was filled out by the researchers. In addition, the patients completed a specific questionnaire with 20 questions about quality of life (Annex) that was performed specifically for the study. This questionnaire was created by the researchers on the basis of AS-20(13). Its purpose was to assess patient interaction within social and working environments, sensory perception, and daily life limitations, with five types of answers for each question: never, rarely or very few times, sometimes, frequently, or always. This strategy aimed to facilitate the patient's understanding, make the answering of questions easier, and allow for fewer false-negative answers.

\section{RESULTS}

Totally, 101 individuals aged 7-67 years were interviewed. The average age of patients was 22.7 years, with the majority being $\leq 18$ years $(53.4 \%)$. With regard to the subgroups, a relative predominance of women (61.4\%) was observed. With regard to the type of strabismus, 58.4\% respondents had esotropia, 37.6\% had exotropia, $2 \%$ had dissociated vertical deviation (DVD), $1 \%$ had left eye hypotropia, and $1 \%$ did not have any deviations because he had previously undergone corrective surgery. At the time of the study, the patients were interviewed in the strabismus outpatient department; $75.2 \%$ had not undergone strabismus correction surgery and $24.8 \%$ had already undergone surgery an average of 2.7 years before the interview. The number of answers for each question and the respective percentages are shown in table 1.

For the first question in the quality of life questionnaire, $68.3 \%$ patients always noticed that they had strabismus, and when added together with the answers of "frequently" and "sometimes", this number increased to $83.1 \%$. When asked how frequently strabismus bothered them, $49.5 \%$ reported that it always did, and when combined together with the answers "frequently" and "sometimes", this percentage increased to $74.2 \%$. The majority of the patients (54.4\%) thought that people were always staring at their eyes, and only $15.8 \%$ thought that people never noticed their strabismus. When asked if they felt

Annex. Questionnaire on the impact of strabismus on patient quality of life

\begin{tabular}{|c|c|c|c|c|c|}
\hline Questions & Never & $\begin{array}{c}\text { Rarely or very } \\
\text { few times }\end{array}$ & Sometimes & Frequently & Always \\
\hline \multicolumn{6}{|l|}{ 1- Do you notice you have strabismus (crossed eyes or lazy eyes)? } \\
\hline \multicolumn{6}{|l|}{ 2- Does strabismus bother you? } \\
\hline \multicolumn{6}{|l|}{ 3- When you interact with other people, do you feel they notice your strabismus? } \\
\hline \multicolumn{6}{|l|}{ 4- Do you feel different (inferior) because of strabismus? } \\
\hline \multicolumn{6}{|l|}{ 5- Do you feel that strabismus hinders your performance (at school or at work)? } \\
\hline \multicolumn{6}{|l|}{ 6- Do you feel that strabismus affects your relations with other people? } \\
\hline \multicolumn{6}{|l|}{ 7- Do you feel that your opportunities (social interaction or at work) are fewer because of strabismus? } \\
\hline \multicolumn{6}{|l|}{ 8- Do you imagine what other people are thinking about your eyes? } \\
\hline \multicolumn{6}{|l|}{ 9- Do you have more difficulty in making friends because of strabismus? } \\
\hline \multicolumn{6}{|l|}{ 10- Do you feel uncomfortable if someone asks something about your eyes? } \\
\hline \multicolumn{6}{|l|}{ 11- Do you feel that people avoid looking at you because of strabismus? } \\
\hline \multicolumn{6}{|l|}{ 12- Does strabismus hinder your vision? } \\
\hline \multicolumn{6}{|l|}{ 13- Do you have difficulty in reading because of strabismus? } \\
\hline \multicolumn{6}{|l|}{ 14- Do you feel more stressed out (anxious) because of strabismus? } \\
\hline \multicolumn{6}{|l|}{ 15- Do you have difficulty in depth perception (assess the distance of objects)? } \\
\hline \multicolumn{6}{|c|}{ 16- Do you feel any discomfort such as pain or burning sensation in the eyes because of strabismus? } \\
\hline \multicolumn{6}{|l|}{ 17- Do you have to close one of your eyes to read? } \\
\hline \multicolumn{6}{|l|}{ 18- Do you have diplopia (double vision)? } \\
\hline \multicolumn{6}{|l|}{ 19- Do you feel eye strain because of strabismus? } \\
\hline 20- Do you think about your strabismus so frequently that it hinders your concentration? & & & & & \\
\hline
\end{tabular}


inferior because of the strabismus, $41.5 \%$ reported that they always did. If we considered the answers "sometimes" and "frequently", this percentage increased to $58.4 \%$. Of all the interviewed patients, $22.7 \%$ felt that strabismus affected their performance at school or work.

In terms of their relationships with other people, 53\% patients felt that strabismus affected their interpersonal relationships at some point in their lives. Of those patients, $22 \%$ felt that this was a constant problem. They were asked if social interaction and job opportunities were diminished because of strabismus, and $44.5 \%$ answered that it always, frequently, or sometimes happened in their lives.

The majority of patients (71.2\%) imagined what other people thought about their eyes, and $34.6 \%$ observed the same. The majority of the patients (62.3\%) answered that strabismus never prevented them from making friends, but $16.8 \%$ felt that it always interfered. The majority of patients (62.3\%) always, frequently, or sometimes felt upset when somebody asked them about their eyes, and $16.8 \%$ felt that people frequently or always avoided looking at them.

When asked if strabismus hindered their vision, $22.7 \%$ answered that they were frequently or always impaired by their problem, and $12.1 \%$ said that they had difficulty in reading because of strabismus. With regard to an increase in anxiety related to strabismus, $27.7 \%$ were always or frequently anxious. When asked about their assessment of depth perception or the evaluation of the distance between objects, $11 \%$ patients reported that they always faced this difficulty. Pain or burning sensation in the eyes was also associated with strabismus; $57.4 \%$ patients felt some kind of discomfort. Of all the patients interviewed, $84 \%$ reported that they never had to close one eye while reading. The majority of patients $(82.1 \%)$ did not complain of double vision, but this always happened to $4.9 \%$. Many patients related eye strain with strabismus, $26.7 \%$ sometimes felt eye strain, and $18.8 \%$ always or frequently felt eye strain. In addition, many patients reported attention deficits related to the problem: 19.8\% always experienced them and $26.7 \%$ sometimes or frequently experienced them.

A significant difference was detected in quality of life scores for the psychosocial aspect between patients who had and had not undergone surgery (Wilcoxon test, 158; $p<0.001$ ). Individuals who underwent surgery had a better quality of life from the psychosocial aspect (the median value for individuals who did not undergo surgery was -0.467 , while that for those who underwent surgery was 1.095). The same difference was detected for the total quality of life score (Wilcoxon test, 169; $p<0.001$ ). Individuals who underwent surgery had a better total quality of life (the median value for individuals who did not undergo surgery was -0.475 , while that for individuals who underwent surgery was 1.21). No significant difference was detected at the $5 \%$ level in the functional aspect of the quality of life score between individuals who had and had not undergone surgery.

\section{DISCUSSION}

Some quality of life studies have demonstrated that strabismus may have a more harmful effect than diabetic retinopathy, macular degeneration, or a mild cerebrovascular accident ${ }^{(18)}$. This study demonstrated that strabismus in adults was associated not only with functional effects but also with psychosocial negative effects; both can have a great influence on all aspects of the patient's life.

Reports of the psychosocial negative effects of strabismus in adults were published in 1993; the patients said that every aspect of their lives was affected by strabismus, such as self-esteem, employment prospects, interpersonal relationships, education, and playing sports ${ }^{(19)}$. More severe manifestations have been observed, including an increase in the occurrence of psychiatric disorders in young adults with strabismus, particularly exotropia. A study determined that $41.3 \%$ patients with strabismus developed mental health problems compared with $30.7 \%$ from the control group ${ }^{(20,21)}$

In order to assess the quality of life, it is necessary to focus on the problems associated with the disease of interest. Therefore, it is important to develop specific assessment tools. Previous studies have quantified the negative effects of strabismus using a variety of generic questionnaires that were nonspecific for strabismus, such as the Time Trade-Off (TTO) (how much time of their life they would use to achieve perfect vision) or the Standard Gamble (SG: what would they risk in order to achieve perfect vision). According to the former, there was a $3.7 \%$ decrease in quality of life $e^{(20,22,23)}$.

Table 1. Answers for the 20 questions (Q1 to Q20) with absolute numbers and the percentage for each one of them in brackets

\begin{tabular}{|c|c|c|c|c|c|}
\hline & Never & Rarely or very few times & Sometimes & Frequently & Always \\
\hline Q1 & $16(15.84)$ & $1(0.99)$ & $12(11.88)$ & $3(2.97)$ & $69(68.32)$ \\
\hline Q2 & $18(17.82)$ & $8(7.92)$ & $21(20.79)$ & $4(3.96)$ & $50(49.50)$ \\
\hline Q4 & $38(37.62)$ & $4(3.96)$ & $14(13.86)$ & $3(2.97)$ & $42(41.58)$ \\
\hline Q5 & $52(51.49)$ & $7(6.93)$ & $14(13.86)$ & $5(4.95)$ & $23(22.77)$ \\
\hline Q6 & $48(47.52)$ & $10(9.90)$ & $18(17.82)$ & $3(2.97)$ & $22(21.78)$ \\
\hline Q8 & $29(28.71)$ & $5(4.95)$ & $26(25.74)$ & $6(5.94)$ & $35(34.65)$ \\
\hline Q9 & $63(62.38)$ & $2(1.98)$ & $17(16.83)$ & $2(1.98)$ & $17(16.83)$ \\
\hline Q10 & $36(35.64)$ & $2(1.98)$ & $27(26.73)$ & $3(2.97)$ & $33(32.67)$ \\
\hline Q11 & $59(58.42)$ & $7(6.93)$ & $18(17.82)$ & $2(1.98)$ & $15(14.85)$ \\
\hline Q12 & $58(57.43)$ & $8(7.92)$ & $12(11.88)$ & $5(4.95)$ & $18(17.82)$ \\
\hline Q17 & $84(83.16)$ & $2(1.98)$ & $9(8.91)$ & $0(0.00)$ & $6(5.94)$ \\
\hline Q18 & $83(82.18)$ & $3(2.97)$ & $9(8.91)$ & $1(0.99)$ & $5(4.95)$ \\
\hline Q19 & $52(51.49)$ & $3(2.97)$ & $27(26.73)$ & $6(5.94)$ & $13(12.87)$ \\
\hline Q20 & $52(51.49)$ & $2(1.98)$ & $18(17.82)$ & $9(8.91)$ & $20(19.80)$ \\
\hline
\end{tabular}




\section{CONCLUSIONS}

In our study, we managed to capture the perception of younger individuals aged $>7$ years, which is the age at which a child can recognize the interference of strabismus with the functional and psychosocial aspects of his or her life. Our study demonstrated that strabismus interfered with patient quality of life. A significant variation was observed in the psychosocial aspect of quality of life between patients who had and had not undergone surgical treatment. With this information, new studies can be conducted for the assessment of quality of life before and after surgical treatment in patients with strabismus.

\section{REFERENCES}

1. Leske DA, Hatt SR, Holmes JM. Test-retest reliability of health-related quality-of-life questionnaires in adults with strabismus. Am J Ophthalmol. 2010;149(4):672-6.

2. Assaf AA. The sensitive period: transfer of fixation after occlusion for strabismic amblyopia. Br J Ophthalmol. 1982;66(1):64-70.

3. Von Noorden GK. Binocular vision and ocular motility. $4^{\text {th }}$ ed. St Louis: Mosby: 1990

4. Pediatric Eye Disease Investigator Group. A randomized trial of atropine vs. patching for treatment of moderate amblyopia in children. Arch Ophthalmol. 2002;120(3):268-78. Comment in: Arch Ophthalmol. 2002;120(3):387-8.

5. Van Leeuwen R, Eijkemans MJ, Vingerling JR, Hofman A, de Jong PT, Simonsz HJ. Risk of bilateral visual impairment in individuals with amblyopia: the Rotterdam study. $\mathrm{Br}$ J Ophthalmol. 2007;91(11):1450-1. Comment in: Br J Ophthalmol. 2007;91(11):1417-8.

6. Rahi J, Logan S, Timms C, Russell-Eggitt I, Taylor D. Risk, causes, and outcomes of visual impairment after loss of vision in the non-amblyopic eye: A population-based study. Lancet. 2002;360(9333):597-602.

7. Packwood EA, Cruz OA, Rychwalski PJ, Keech RV. The psychosocial effects of amblyopia study. J AAPOS. 1999;3(1):15-7.

8. Chua B, Mitchell P. Consequences of amblyopia on education, occupation, and long term vision loss. Br J Ophthalmol. 2004;88(9):1119-21. Comment in: Br J Ophthalmol. 2004;88(9):1105-6.
9. van de Graaf ES, van Kempen-du Saar H, Looman CW, Simonsz HJ. Utility analysis of disability caused by amblyopia and/or strabismus in a population-based, historic cohort. Graefes Arch Clin Exp Ophthalmol. 2010;248(12):1803-7.

10. Kothari M, Balankhes S, Gawade R, Toshnival S. Comparison of psychosocial and emotional consequences of childhood strabismus on the families from rural and urban India. Indian J Ophthalmol. 2009;57(4):285-8. Comment in: Indian J Ophthalmol. 2010; 58(3):257-8; author reply 258-9.

11. Jackson S, Harrad RA, Morris M, Rumsey N. The psychosocial benefits of corrective surgery for adults with strabismus. Br J Ophthalmol. 2006;90(7):883-8.

12. Beauchamp GR, Felius J, Stager DR, Beauchamp CL. The utility of strabismus in adults. Trans Am Ophthalmol Soc. 2005;103:164-71; discussion 171-2.

13. Hatt SR, Leske DA, Bradley EA, Cole SR, Holmes JM. Comparison of quality-of-life instruments in adults with strabismus. Am J Ophthalmol. 2009;148(4):558-62.

14. van de Graaf ES, Felius J, van Kempen-du Saar H, Looman CW, Passchier J, Kelderman $\mathrm{H}$, et al. Construct validation of the Amblyopia and Strabismus Questionnaire (A\&SQ) by factor analysis. Graefes Arch Clin Exp Ophthalmol. 2009;247(9):1263-8.

15. Hatt SR, Leske DA, Bradley EA, Cole SR, Holmes JM. Development of a quality-of-life questionnaire for adults with strabismus. Ophthalmology. 2009;116(1):139-44.

16. Hatt SR, Leske DA, Adams WE, Kirgis PA, Bradley EA, Holmes JM. Quality of life in intermittent exotropia: child and parent concerns. Arch Ophthalmol. 2008;126(11):1525-9.

17. Hatt SR, Leske DA, Kirgis PA, Bradley EA, Holmes JM. The effects of strabismus on quality of life in adults. Am J Ophthalmol. 2007:144(5):643-7.

18. Beauchamp CL, Beauchamp GR, Stager DR Sr, Brown MM, Brown GC, Felius J. The cost utility of strabismus surgery in adults. J AAPOS. 2006;10(5):394-9.

19. Satterfield D, Keltner JL, Morrison TL. Psychosocial aspects of strabismus study. Arch Ophthalmol. 1993;111(8):1100-5. Comment in: Arch Ophthalmol. 1994;112(3):302.

20. Bez Y, Coskun E, Erol K, Cingu AK, Eren Z, Topçuoglu V, et al. Adult strabismus and social phobia: a case-controlled study. J AAPOS. 2009;13(3):249-52.

21. Mohney BG, McKenzie JA, Capo JA, Nusz KJ, Mrazek D, Diehl NN. Mental illness in young adults who had strabismus as children. Pediatrics. 2008;122(5):1033-8.

22. Chua B, Mitchell P. Consequences of amblyopia on education, occupation, and long term vision loss. Br J Ophthalmol. 2004:88(9):1119-21. Comment in: Br J Ophthalmol. 2004;88(9):1105-6.

23. Archer SM, Musch DC, Wren PA, Guire KE, Del Monte MA. Social and emotional impact of strabismus surgery on quality of life in children. J AAPOS. 2005;9(2):148-51.

\title{
20 \\ $12^{\circ}$ Congresso SOTRIM - \\ Sociedade de Oftalmologia do Triângulo Mineiro
}

\author{
6 a 8 de novembro de 2014 \\ Universidade Federal do Triângulo Mineiro (CEA) \\ Uberaba - MG
}

Informações:

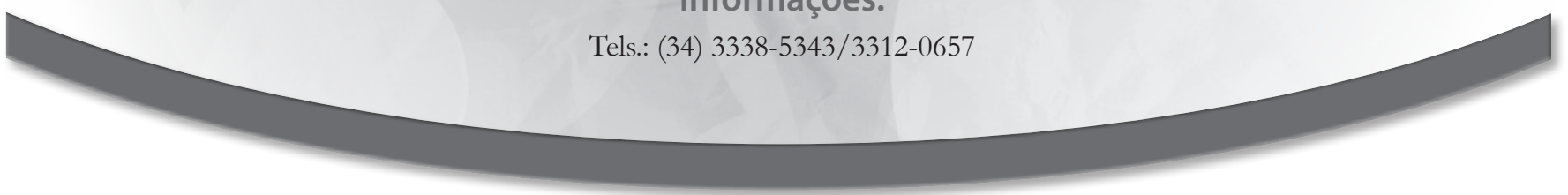

